\title{
Food Intake in Free-feeding and Energy-deprived Lean Rats Is Mediated by the Neuropeptide $\mathrm{Y}_{5}$ Receptor
}

\author{
Leoluca Criscione, ${ }^{*}$ Pascal Rigollier, ${ }^{*}$ Christine Batzl-Hartmann, ${ }^{*}$ Heinrich Rüeger, ${ }^{*}$ Alain Stricker-Krongrad, ${ }^{*}$ Philipp Wyss, ${ }^{*}$ \\ Liliane Brunner, ${ }^{\star}$ Steven Whitebread, ${ }^{*}$ Yasuchika Yamaguchi, ${ }^{*}$ Christoph Gerald, ${ }^{\ddagger}$ Rainer O. Heurich, ${ }^{\ddagger}$ Mary W. Walker, ${ }^{\star}$ \\ Michele Chiesi, ${ }^{*}$ Walter Schilling, ${ }^{\star}$ Karl G. Hofbauer, ${ }^{*}$ and Nigel Levens ${ }^{\star}$ \\ * Metabolic and Cardiovascular Diseases Research, Novartis Pharma AG, CH-4002 Basel, Switzerland; and ${ }^{\ddagger}$ Synaptic Pharmaceutical \\ Corporation, Paramus, New Jersey 07652
}

\begin{abstract}
The new neuropeptide $\mathrm{Y}(\mathrm{NPY}) \mathrm{Y}_{5}$ receptor antagonist CGP 71683A displayed high affinity for the cloned rat NPY $\mathrm{Y}_{5}$ subtype, but $>1,000$-fold lower affinity for the cloned rat NPY $Y_{1}, Y_{2}$, and $Y_{4}$ subtypes. In LMTK cells transfected with the human NPY $Y_{5}$ receptor, CGP 71683A was without intrinsic activity and antagonized NPY-induced $\mathrm{Ca}^{2+}$ transients. CGP 71683A was given intraperitoneally (dose range $1-100 \mathrm{mg} / \mathrm{kg}$ ) to a series of animal models of high hypothalamic NPY levels. In lean satiated rats CGP 71683A significantly antagonized the increase in food intake induced by intracerebroventricular injection of NPY. In 24-h fasted and streptozotocin diabetic rats CGP 71683A dosedependently inhibited food intake. During the dark phase, CGP 71683A dose-dependently inhibited food intake in free-feeding lean rats without affecting the normal pattern of food intake or inducing taste aversion. In free-feeding lean rats, intraperitoneal administration of CGP 71683A for $28 \mathrm{~d}$ inhibited food intake dose-dependently with a maximum reduction observed on days 3 and 4 . Despite the return of food intake to control levels, body weight and the peripheral fat mass remained significantly reduced. The data demonstrate that the NPY $Y_{5}$ receptor subtype plays a role in NPY-induced food intake, but also suggest that, with chronic blockade, counterregulatory mechanisms are induced to restore appetite. (J. Clin. Invest. 1998. 102:21362145.) Key words: obesity • energy metabolism • weight reduction • neuropeptide $\mathrm{Y} \bullet$ insulin
\end{abstract}

\section{Introduction}

Within the hypothalamus, neuropeptide $\mathrm{Y}(\mathrm{NPY})^{1}$ is intimately involved in the regulation of several aspects of neuroendocrine function and behavior, in particular food intake

Address correspondence to Leoluca Criscione, Novartis Pharma AG, K-125.801, CH-4002 Basel, Switzerland. Phone: 41-61-6965137; FAX: 41-61-6965561; E-mail: Leoluca.criscione@pharma.novartis.com

Received for publication 4 June 1998 and accepted in revised form 28 October 1998.

1. Abbreviations used in this paper: $\mathrm{ARC}$, arcuate nucleus; $\mathrm{DMH}$, dorsomedial hypothalamus; hPYY, human peptide YY; NPY, neuropeptide Y; PVN, paraventricular nucleus.

J. Clin. Invest.

(C) The American Society for Clinical Investigation, Inc. 0021-9738/98/12/2136/10 \$2.00

Volume 102, Number 12, December 1998, 2136-2145

http://www.jci.org
(1). For example, acute injection of NPY into the cerebral ventricles or directly into the hypothalamus leads to substantially increased food intake in satiated rats $(2,3)$. In free-feeding rats, both hypothalamic NPY and NPY mRNA are increased on transition from the light to the dark phase of the day/night cycle whereas, in both fasted and streptozotocin diabetic rats, two models of energy deficit, NPY levels and NPY mRNA are also increased in this brain region (4-11).

A temporal relationship between increased hypothalamic NPY levels and food intake has been established $(12,13)$. Furthermore, inhibition of NPY synthesis or blockade of the actions of NPY with antibodies or NPY antisense oligonucleotides has been shown to reduce food intake in both free-feeding and food-deprived rats (14-16). These studies, along with the changes in NPY levels in the hypothalamus described above, all suggest that NPY plays a physiologically important role in the control of food intake in both normal and energydeprived rats.

The actions of NPY are believed to be mediated by several receptor subtypes named NPY $Y_{1}-Y_{6}(17)$. Recent studies correlating the NPY $\mathrm{Y}_{5}$ binding affinity of a range of NPY peptide agonists with their ability to induce food intake suggest that this receptor subtype is intimately involved in NPY-induced feeding $(18,19)$. This conclusion is supported by the substantial reduction in food intake observed in fasted rats after intracerebroventricular injection of antisense oligonucleotides directed against the NPY $\mathrm{Y}_{5}$ receptor $(20,21)$. However, clouding the issue are observations with selective peptide agonists and nonpeptide antagonists pointing to the involvement of the NPY $Y_{1}$ receptor or other, currently unidentified receptor subtypes in the control of NPY-induced food intake (2227). Therefore, despite extensive investigation, these conflicting observations have not enabled a definition of the receptor subtype(s) mediating the increase in food intake produced by NPY to be clearly established.

In view of the above controversy, the purpose of the following experiments was to investigate the hypothesis that the NPY $\mathrm{Y}_{5}$ receptor subtype plays a major role in mediating food intake induced by NPY. This hypothesis was examined by studying NPY-induced feeding behavior in response to blockade of NPY $Y_{5}$ receptors with a new highly selective nonpeptide antagonist, CGP 71683A.

\section{Methods}

Animals. These studies were conducted with lean male SpragueDawley rats (250-380 g, Tif: RA25; Novartis Pharma AG, Basel, Switzerland). The animals were maintained in rooms with a 12-h light/dark cycle (light 8 a.m. to 8 p.m.) at $20-24^{\circ} \mathrm{C}$ and controlled humidity. All animals were given tap water to drink and were maintained on a normal pellet diet (NAFAG, Gossau, Switzerland) for at least $1 \mathrm{wk}$ before use in the following experiments. 
Determination of the binding affinity of CGP 71683A to rat NPY receptor subtypes. HEK-293 cells stably expressing the rat NPY $\mathrm{Y}_{5}$ receptor subtype or LMTK cells stably expressing the rat NPY $Y_{1}, Y_{2}$, or $\mathrm{Y}_{4}$ receptor subtypes (18) were homogenized in ice-cold hypotonic buffer (Tris- $\mathrm{HCl} 20 \mathrm{mM}$, EDTA $5 \mathrm{mM}$; pH 7.7 at $4^{\circ} \mathrm{C}$ ). The homogenate was centrifuged at $32,000 \mathrm{~g}$ for $20 \mathrm{~min}$ at $4^{\circ} \mathrm{C}$ and the resultant pellet was resuspended in the same buffer and recentrifuged. The final pellet was suspended at room temperature in Hepes buffer (Hepes $20 \mathrm{mM}, \mathrm{NaCl} 10 \mathrm{mM}, \mathrm{CaCl}_{2} 1.26 \mathrm{mM}, \mathrm{MgSO}_{4} 0.81 \mathrm{mM}$, $\mathrm{KH}_{2} \mathrm{PO}_{4} 0.22 \mathrm{mM}, \mathrm{pH}$ 7.4). Shortly before use, $0.1 \%$ BSA was added. The protein content of the pellet was determined by the method of Bradford using BSA as standard (28).

Competition binding studies were performed in Millipore Multiscreen FB filter plates at room temperature for $2 \mathrm{~h}$. The filters in each well were pretreated with $2 \%$ polyethyleneimine for $30 \mathrm{~min}$ and rinsed once with $300 \mu \mathrm{l}$ Hepes buffer before use. The following were pipetted into each well: $60 \mu \mathrm{l}$ Hepes buffer, $20 \mu{ }^{125} \mathrm{I}$-[Pro $\left.{ }^{34}\right]$ human peptide YY (hPYY) (for the NPY $Y_{1}, Y_{4}$, and $Y_{5}$ binding studies or ${ }^{125} \mathrm{I}$-hPYY for the NPY $\mathrm{Y}_{2}$ binding studies; $600 \mathrm{pM}$; Anawa, Wangen, Switzerland) in Hepes buffer; $20 \mu l$ CGP 71683A in Hepes buffer plus $10 \%$ DMSO (or Hepes buffer plus 10\% DMSO for the controls); 100 $\mu \mathrm{l}$ crude membrane suspension $(\sim 10 \mu \mathrm{g}$ protein $)$. The incubations were terminated by rapid filtration and washing four times with 300 $\mu l$ PBS. The filters were removed from the wells, placed into plastic tubes, and counted in a $\gamma$-counter (Wallac, Turku, Finland). Nonspecific binding was defined as the binding remaining in the presence of $1 \mu \mathrm{M}$ unlabeled $\left[\mathrm{Pro}^{34}\right] \mathrm{hPYY}$ (for the NPY $\mathrm{Y}_{1}, \mathrm{Y}_{4}$, and $\mathrm{Y}_{5}$ binding studies) or hPYY (for the NPY $\mathrm{Y}_{2}$ binding studies).

Measurement of intracellular $\mathrm{Ca}^{2+}$ transients in LMTK cells stably expressing the human NPY $Y_{5}$ receptor. T175 NUNC plates of confluent LMTK cells were harvested in EDTA/PBS medium, washed in PBS, and then loaded for $90 \mathrm{~min}$ at room temperature with $10 \mu \mathrm{M}$ FLUO-3 AM in $120 \mathrm{mM} \mathrm{NaCl}, 1 \mathrm{mM} \mathrm{MgCl} 2,5.4 \mathrm{mM} \mathrm{KCl}, 0.33 \mathrm{mM} \mathrm{NaH}_{2} \mathrm{PO}_{4}$, $11 \mathrm{mM}$ glucose, $5 \mathrm{mM}$ taurine, $2 \mathrm{mM}$ Na-pyruvate, $1.5 \mathrm{mM}$ L-glutamine, $10 \mathrm{U} /$ liter insulin, $0.1 \% \mathrm{BSA}, 1 \mathrm{mM} \mathrm{CaCl}$, and $10 \mathrm{mM}$ Hepes, $\mathrm{pH} 7.4$, supplemented with pluronic acid $(10 \mathrm{ml} /$ plate $)$. After centrifugation, the cells were resuspended at a concentration of 5-6 million cells $/ \mathrm{ml}$ in buffer (see above) supplemented with $250 \mu \mathrm{M}$ sulfinpyrazone.

Intracellular $\mathrm{Ca}^{2+}$ transients were measured at room temperature in a microtiter plate using a Cytofluor 2350 fluorometer (Millipore Corp., Bedford, MA) with wavelength settings at $485 \mathrm{~nm}$ for excitation and $530 \mathrm{~nm}$ for emission. The ability of NPY or other compounds to induce $\mathrm{Ca}^{2+}$ transients was determined in triplicate by adding $30 \mu \mathrm{l}$ of the agent (dissolved in $2 \mu \mathrm{l}$ DMSO and diluted with $28 \mu \mathrm{l}$ of buffer) to $170 \mu \mathrm{l}$ of cells. Antagonistic activity was determined in triplicate by incubating $170 \mu \mathrm{l}$ cells at room temperature in the presence of various quantities of compounds dissolved in $2 \mu \mathrm{l}$ DMSO (or $2 \mu \mathrm{l}$ DMSO for the controls) for $5 \mathrm{~min}$. Thereafter, $30 \mu \mathrm{l}$ of human NPY in buffer was added to reach a final concentration of $100 \mathrm{nM}$ and intracellular $\mathrm{Ca}^{2+}$ changes were monitored. After $10 \mathrm{~min}$, when the intracellular $\mathrm{Ca}^{2+}$ concentration had returned to basal levels, $30 \mu \mathrm{l}$ of the thrombin receptor agonist peptide Ser-( $p$-Fluoro)Phe-Leu( $\beta$-cyclohexyl)Ala-ArgNH $\mathrm{H}_{2}$ (TRAP) was added to reach a final concentration of $10 \mu \mathrm{M}$. NPY selective antagonists should show no effect on TRAP-induced $\mathrm{Ca}^{2+}$ transients. $\mathrm{Ca}^{2+}$ transient curves were obtained after subtraction of the control curves. The compound concentration giving $50 \%$ inhibition of the maximum of the $\mathrm{Ca}^{2+}$ transients induced by NPY was then calculated.

Intracerebroventricular cannulation. Under pentobarbital anesthesia $(50 \mathrm{mg} / \mathrm{kg}$ i.p.; Veterinaria AG, Zurich, Switzerland) each rat was stereotaxically implanted with an 8 -mm-long guide cannula (0.6 $\mathrm{mm}$ O.D., $0.35 \mathrm{~mm}$ I.D.) aimed at the right lateral ventricle. With the incisor bar set $2 \mathrm{~mm}$ below the interaural line, the stereotaxic coordinates were $-0.8 \mathrm{~mm}$ anterior and $+1.3 \mathrm{~mm}$ lateral to the bregma. The rats were allowed $7 \mathrm{~d}$ of recovery, during which they were handled daily to minimize nonspecific stress. On the first day of study, all animals received an intracerebroventricular injection of human angiotensin II (150 ng/rat, Hypertensin; Novartis Pharma AG). Only those animals that responded with a sustained drinking response within 2 min were used in the following experiments, which were performed $1 \mathrm{wk}$ after the injection of angiotensin II.

Measurement of food intake. In the majority of experiments described in these studies, food intake was assessed after placing the rats into individual plastic metabolism cages (Techniplast; Indulab, Garns, Switzerland). During these studies the rats had free access to powdered regular food and tap water. After $6 \mathrm{~d}$ of habituation to their new environment, food intake over both the light and dark phases was measured, to establish baseline food intake for each animal. Thereafter, the rats were randomly assigned to either vehicle- or drug-treatment groups. At 8 a.m. on the day of study, the animals were injected intraperitoneally with either vehicle (10\% DMSO, 2 $\mathrm{ml} / \mathrm{kg}$ ) or differing doses of CGP 71683A in vehicle. Food intake was then measured for time periods up to $24 \mathrm{~h}$ (acute experiments, single intraperitoneal injection) or over the complete light and dark phases for times up to $28 \mathrm{~d}$ (chronic experiments, single daily intraperitoneal injections). Because of their design, food spillage from the metabolism cages was minimal and was not corrected for.

For practical reasons, experiments involving the intracerebroventricular injection of NPY were performed individually in wire-topped plastic cages. Before the test procedure, a preweighed quantity of food (five pellets weighing $\sim 45 \mathrm{~g}$ ) was placed on the roof grids. At 8 a.m. on the day of study, each rat was injected intracerebroventricularly with either 300 pmol NPY or an equivalent volume of the artificial cerebrospinal fluid vehicle $(10 \mu \mathrm{l})$ and then returned to their cages. After injection, the food on the cages was weighed at 1-h intervals for the remainder of the experimental period. Food spillage was monitored and, if necessary, food intake was corrected for this.

Measurement of water intake. Rats were maintained in plastic metabolism cages as described above. After $6 \mathrm{~d}$ of habituation to their new environment, both water and food intake over the light and dark phases were measured to establish baseline values for each animal. Thereafter, the rats were randomly assigned to either vehicle or drug treatment groups and deprived of both food and water for the 24-h period before study. At 8 a.m. on the day of study, the animals were injected intraperitoneally with either vehicle (10\% DMSO, 2 $\mathrm{ml} / \mathrm{kg}$ ) or differing doses of CGP $71683 \mathrm{~A}$ in vehicle $(1,10$, and 100 $\mathrm{mg} / \mathrm{kg}$ ). Water intake was then measured for time periods up to $24 \mathrm{~h}$.

Measurement of the pattern of food intake. Each cage included a complete automatic feeding system connected to a computer. After 2 wk of habituation, all rats were injected intraperitoneally either with vehicle (10\% DMSO, $2 \mathrm{ml} / \mathrm{kg}$ ) or with $10 \mathrm{mg} / \mathrm{kg}$ CGP $71683 \mathrm{~A}$ dissolved in vehicle. All injections were performed at the beginning of the light period ( 8 a.m.). After injection, the animals were put back into the feeding system and their feeding behavior was analyzed until the end of the dark period, e.g., during the $24 \mathrm{~h}$ that followed injection. Before the first injection, an intraanimal calculation was performed three times during a minimum of $24 \mathrm{~h}$ to ensure that the animals were well adapted to the system.

A meal was defined as ingestion of a minimum of $0.2 \mathrm{~g}$ of the diet followed by at least 10 min during which no feeding occurred. The following dependent variables and derived measures were calculated as the mean of each variable for each animal: meal number, total amount of food eaten $(\mathrm{g})$, meal intervals $(\mathrm{min})$, meal size $(\mathrm{g})$, meal duration $(\mathrm{min})$, eating rate $(\mathrm{g} / \mathrm{min})$, and time to first meal ( $\mathrm{min})$. Recording of the impulses generated was performed by a microcomputer through an in/out interface (Ciba Pharma Electronic PH2, DA32; Buxco Electronics, Sharon, CT). Data from the feeding system were analyzed with specific software developed in Excel ${ }^{\mathrm{TM}}$ (version 5.1) (29).

Conditioned taste aversion. Conditioned taste aversion in response to CGP 71683A was adapted from previously published methods (30, 31). The rats in this study were maintained individually in plastic cages and, after a 7-d habituation period, were deprived of water for 14 h (12 p.m. to 2 p.m.) on each of five consecutive days (training sessions). During this period, water was returned to the animals for the remaining $10 \mathrm{~h}$ after water deprivation. Water intake within the first 
$50 \mathrm{~min}$ (day 1), $30 \mathrm{~min}$ (days 2 and 3), and $20 \mathrm{~min}$ of water repletion (days 4 and 5) was measured by weighing the drinking bottles. $2 \mathrm{~d}$ after the last water deprivation, the animals were water deprived for $14 \mathrm{~h}$ but offered a solution of sodium saccharine $(0.2 \% \mathrm{wt} / \mathrm{vol})$ instead of water (test day 1). The intake of the saccharine solution was measured for $20 \mathrm{~min}$ and, $15 \mathrm{~min}$ later, the animals were injected intraperitoneally with either a solution of lithium chloride (10,100, and 1,000 $\mu \mathrm{mol} / \mathrm{kg}$ ) or CGP 71683A (1, 10, and $100 \mathrm{mg} / \mathrm{kg}$ ). Control animals received an equal volume of the $10 \%$ DMSO vehicle solution $(2 \mathrm{ml} / \mathrm{kg}$, i.p.). $2 \mathrm{~d}$ later, after $14 \mathrm{~h}$ of water deprivation, the rats were offered the saccharine solution again and the quantity consumed in 20 min was measured (test day 2). Conditioned taste aversion was determined as saccharine intake $(\mathrm{ml} / 20 \mathrm{~min})$ in the lithium chloride-treated or CGP 71683A-treated rats compared with controls on test day 2.

Streptozotocin diabetic rats. Rats were injected intraperitoneally with streptozotocin $(65-70 \mathrm{mg} / \mathrm{kg})$ or the $1 \%$ ascorbic acid vehicle (2 $\mathrm{ml} / \mathrm{kg}$ ). Because of the large number of rats studied (60), the experiments had to be conducted in two equal groups. $2 \mathrm{wk}$ after injection, the rats were placed into metabolism cages and randomly assigned to one of four treatment groups in a balanced design. After $3 \mathrm{~d}$ of habituation, each group of rats was injected intraperitoneally at the beginning of the light phase with either CGP 71683A $(1,10$, and $100 \mathrm{mg} / \mathrm{kg}$ ) or the $10 \%$ DMSO vehicle $(2 \mathrm{ml} / \mathrm{kg})$. Cumulative food intake was measured at various time intervals over the next 24-h period. At the end of the experiment, each rat was decapitated and the trunk blood was collected into ice-cold heparinized tubes. The blood was centrifuged at $4^{\circ} \mathrm{C}$ and the plasma was harvested and stored frozen at $-80^{\circ} \mathrm{C}$ before the measurement of plasma glucose and insulin concentrations. In the first group of rats those animals exhibiting plasma insulin levels $>2 \mathrm{ng} / \mathrm{ml}$, an indication that diabetes had not been induced, were excluded from the subsequent data analysis. It was noted in the first group of rats that those animals having average food intakes in the $48 \mathrm{~h}$ before study of $>28 \mathrm{~g} / 24 \mathrm{~h}$ were normally those with plasma insulin $>2 \mathrm{ng} / \mathrm{ml}$. Therefore, in the second experimental group, four animals that had food intakes $>28 \mathrm{~g} / 24 \mathrm{~h}$ before the study were excluded from the study prior to the injection of CGP 71683A. None of the remaining animals in the second group had plasma insulin $>2 \mathrm{ng} / \mathrm{ml}$.

Plasma measurements. Glucose was measured with an enzymatic method using a commercially available reagent (Beckman, Galway, Ireland). Plasma insulin was determined by radioimmunoassay using a commercially available kit (Sorin Biomedica, Saluggia, Italy). Triglycerides were also measured with a commercially available kit (TRIG; Hoffmann-La Roche, Grenzach, Germany).

Materials. The NPY $\mathrm{Y}_{5}$ antagonist (trans-naphthalene-1-sulfonic acid \{4-[(4-amino-quinazolin-2-ylamino)-methyl]-cyclohexylmethyl\}amide hydrochloride; CGP 71683A) was synthesized by Novartis Pharma AG. The structure of CGP 71683A is shown in Fig. 1. Insulin (Actrapid HM) was obtained from Novo Nordisk Pharma (Kuesnacht, Switzerland). Human NPY was obtained from Bachem (Bubendorf, Switzerland) and FLUO-3 AM from Molecular Probes Europe BV (Leiden, Holland). The thrombin receptor agonist peptide TRAP was synthesized by Novartis Pharma AG. The cell lines stably transfected with the rat NPY receptors were obtained from Synaptic Pharmaceutical Corp. (Paramus, NJ).

Statistics and data analysis. Generally, where parameters were followed as a function of time, the data were statistically analyzed by univariate two-way ANOVA with repeated measures for time (see Figs. 4-5 and 7-10). The analysis incorporated the Greenhouse-Geisser correction for departures from the model. In the case of significant drug-time interactions, the Least Significant Difference (LSD) procedure was used to compare the values at each time point in the drugtreated groups with the corresponding time point in the control group of animals. Two-way ANOVA followed by the LSD was used for data analysis in Fig. 3. One-way ANOVA was used for data analysis in Figs. 6 and 10 and in Table III. Unpaired $t$ tests were used for data analysis in Table II. $P<0.05$ (two-tailed) was considered to be statistically significant.

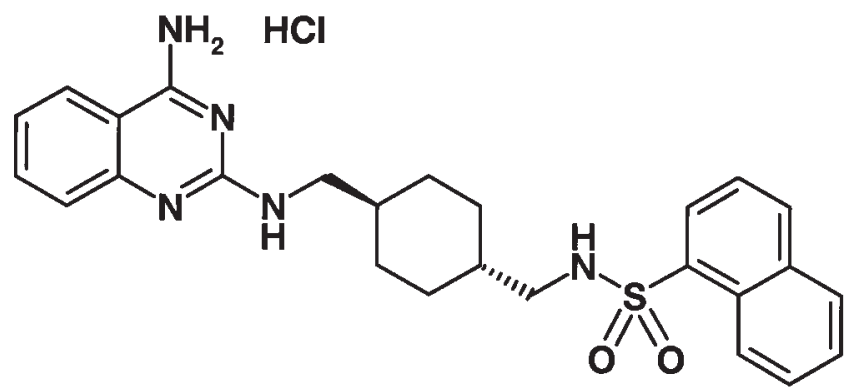

Figure 1. Chemical structure of CGP 71683A.

\section{Results}

Affinity of CGP 71683A to rat NPY receptor subtypes (Table I) CGP 71683A displayed high affinity for the cloned rat NPY $Y_{5}$ receptor $(1.4 \pm 0.09 \mathrm{nM})$ but bound with at least 1,000-fold lower affinity to the $\mathrm{Y}_{1}, \mathrm{Y}_{2}$, and $\mathrm{Y}_{4} \mathrm{NPY}$ receptor subtypes.

Antagonism of NPY-induced intracellular calcium transients in human NPY $Y_{5}$-transfected LMTK mouse fibroblasts by CGP 71683 A (Fig. 2)

The antagonistic properties of CGP 71683A were assessed by measuring the ability of this compound to inhibit NPYinduced $\mathrm{Ca}^{2+}$ transients in mouse fibroblasts. In this cellular model, CGP 71683A inhibited $\mathrm{Ca}^{2+}$ transients induced by $100 \mathrm{nM}$ NPY in a concentration-dependent manner $\left(\mathrm{IC}_{50}=\right.$ $5.8 \pm 1.2 \mathrm{nM}, n=4)$. The suppression of the maximal effects of NPY by increasing concentrations of CGP 71683A is compatible with an insurmountable mode of antagonism. The inhibitory effects of the compound appeared to be selective, since activation of thrombin receptors, which also induced $\mathrm{Ca}^{2+}$ transients in this cell type, was not affected by concentrations of CGP 71683A up to $10 \mu \mathrm{M}$ (results not shown). Furthermore, compounds from our screening program that were not demonstrable NPY $Y_{5}$ receptor antagonists did not affect NPY-induced $\mathrm{Ca}^{2+}$ transients in this cell line (results not shown). When tested alone, CGP 71683A did not elicit $\mathrm{Ca}^{2+}$ transients up to a concentration of $10 \mu \mathrm{M}$, indicating that the compound is devoid of agonistic activity (results not shown).

Effect of CGP 71683A on food intake stimulated by intracerebroventricular injection of NPY (Fig. 3)

Compared with time control values, intracerebroventricular injection of 300 pmol NPY induced a prompt, significant, and sustained increase in food intake. Intraperitoneal injection of

Table I. Ability of CGP 71683A to Compete for

${ }^{125}$ I-[Pro $\left.{ }^{34}\right]$ hPYY Binding to Rat $Y_{1}, Y_{4}$, and $Y_{5}$ Receptors or

${ }^{125} I-h P Y Y$ Binding to the Rat $Y_{2}$ Receptor

\begin{tabular}{lcc} 
NPY receptor & $\mathrm{IC}_{50}$ & $(n)$ \\
\hline & $n M$ & \\
$\mathrm{Y}_{1}$ & $2765 \pm 145$ & $(7)$ \\
$\mathrm{Y}_{2}$ & $7187 \pm 222$ & $(8)$ \\
$\mathrm{Y}_{4}$ & $5637 \pm 1081$ & $(7)$ \\
$\mathrm{Y}_{5}$ & $1.4 \pm 0.09$ & $(8)$
\end{tabular}

Results are expressed as mean \pm SEM. Numbers of experiments are in parentheses. 


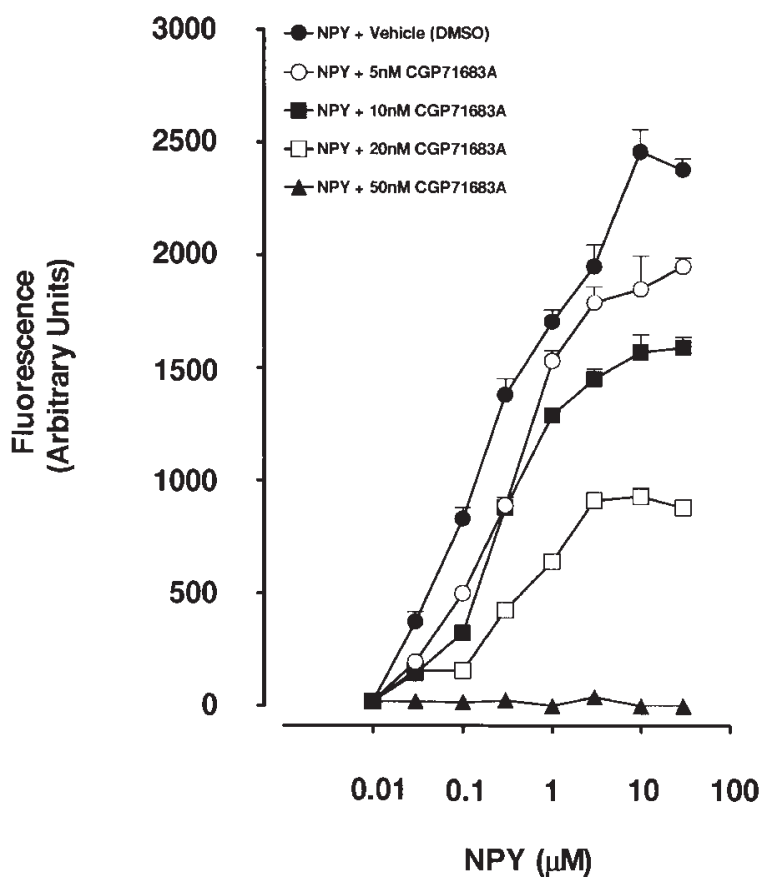

Figure 2. Antagonism of NPY-induced intracellular $\mathrm{Ca}^{2+}$ transients in LMTK mouse fibroblasts by CGP 71683A. Mouse fibroblasts expressing the NPY $\mathrm{Y}_{5}$ receptor were incubated with different concentrations of NPY. The increase in $\mathrm{Ca}^{2+}$ transients induced by NPY in these cells was antagonized dose-dependently by CGP 71683A. Results are expressed as mean \pm SEM from five to six observations at each data point.

CGP 71683A inhibited NPY-induced feeding in a dose-dependent manner. The highest dose given $(10 \mathrm{mg} / \mathrm{kg}$, i.p.) significantly inhibited NPY induced food intake by $\sim 50 \%, 2 \mathrm{~h}$ after treatment. Administration of $10 \mathrm{mg} / \mathrm{kg}$ CGP $71683 \mathrm{~A}$ alone did not significantly affect food intake relative to control values during the 8-h period after injection (see Fig. 4).

\section{Effect of CGP 71683A on food intake in 24- $h$ fasted and} free-feeding rats (Fig. 4)

Fasted rats. Immediately after food was returned to the control animals, they ate rapidly for the first $2 \mathrm{~h}$ and thereafter had eaten more at each time period than observed in freefeeding rats. Injection of CGP 71683A reduced food intake in all phases of the light/dark cycle in a dose-dependent manner. The reduction in food intake induced by CGP 71683A was particularly evident during the dark phase. The highest dose of CGP 71683A administered (100 mg/kg i.p.) reduced food intake virtually completely $2 \mathrm{~h}$ after returning food to the animals.

Free-feeding rats. The results show that rats eat little during the light phase but steadily increase their food intake towards the beginning of the dark phase, during which the majority of their daily food intake is consumed. Injection of CGP 71683A reduced food intake in all phases of the light/dark cycle in a dose-dependent manner. The highest dose of CGP 71683A administered (100 mg/kg i.p.) resulted in essentially complete cessation of food intake for most of the experimental period.

Effect of CGP 71683 A on meal pattern in free-feeding rats (Table II)

In these experiments, rats were injected with CGP 71683A (10 $\mathrm{mg} / \mathrm{kg}$ i.p.) at the beginning of the light phase and changes in the

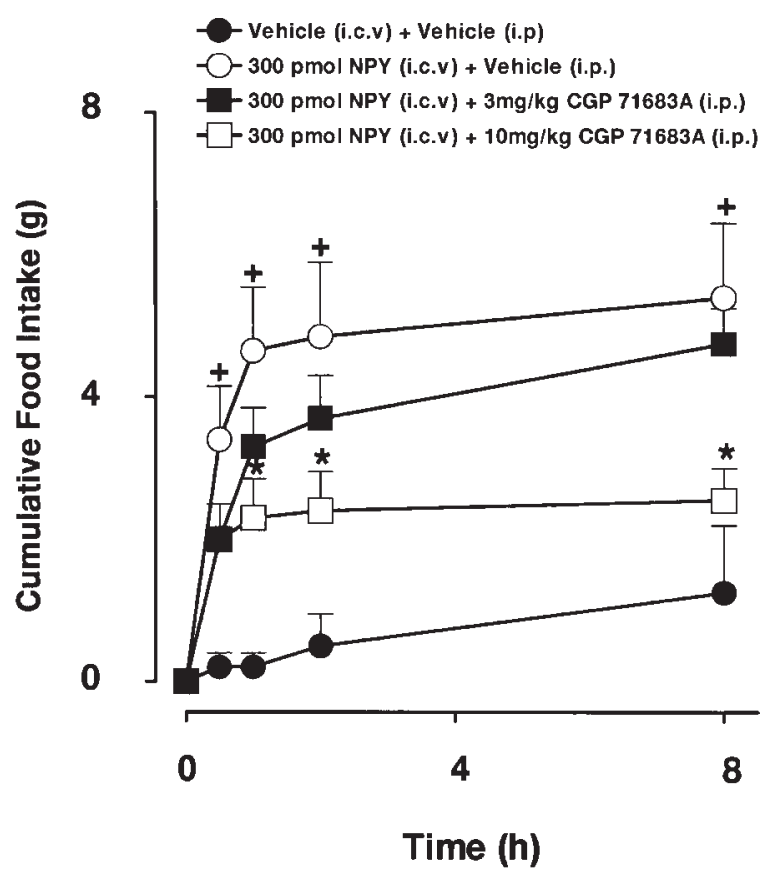

Figure 3. Effect of CGP 71683A on food intake stimulated by intracerebroventricular injection of NPY. Rats were injected intracerebroventricularly with either $300 \mathrm{pmol}$ porcine NPY or an equivalent volume of vehicle $(10 \mu \mathrm{l})$. Changes in food intake were measured over the subsequent 8-h period. In both cases, the $10 \%$ DMSO vehicle for CGP 71683A was injected intraperitoneally $(2 \mathrm{ml} / \mathrm{kg})$. Concurrent intraperitoneal injection of 3 or $10 \mathrm{mg} / \mathrm{kg}$ CGP 71683A inhibited NPY-induced food intake in a dose-dependent manner. Results show mean \pm SEM from five to seven animals in each group, $* P<0.05$ compared with NPY induced food intake. ${ }^{+} P<0.05$ compared with vehicle in the group given NPY.

pattern of food intake were recorded for $24 \mathrm{~h}$ until the end of the dark period. The results show that total food intake as well as meal number, meal size, meal duration, and meal intervals were all significantly decreased compared with vehicle-injected control animals. In contrast, the eating rate during the treatment period was not significantly affected by CGP 71683A. Time to first meal was clearly delayed by NPY $\mathrm{Y}_{5}$ receptor blockade.

Table II. Effect of CGP 71683 A on the Pattern of Food Intake Measured over $24 \mathrm{~h}$ in Free-feeding Rats

\begin{tabular}{lcc}
\hline \multicolumn{1}{c}{ Measured parameter } & Vehicle (10\% DMSO) & CGP 71683A (10 mg/kg) \\
\hline Total food intake $(\mathrm{g})$ & $20.2 \pm 0.7$ & $7.1 \pm 0.9^{*}$ \\
Meal number & 12 & $8^{*}$ \\
Meal size (g) & $1.78 \pm 0.12$ & $0.87 \pm 0.11^{*}$ \\
Meal duration (min) & $26 \pm 3$ & $10 \pm 1^{*}$ \\
Meal intervals (min) & $74 \pm 7$ & $174 \pm 23^{*}$ \\
Eating rate (g/min) & $0.07 \pm 0.01$ & $0.08 \pm 0.01$ \\
Time to first meal (min) & $15.0 \pm 7.0$ & $129.0 \pm 62.0$ \\
& & \\
\hline
\end{tabular}

CGP $71683 \mathrm{~A}(10 \mathrm{mg} / \mathrm{kg})$ or the $10 \%$ DMSO vehicle $(2 \mathrm{ml} / \mathrm{kg})$ was injected intraperitoneally at the beginning of the light phase and the above pattern of food intake was measured over $24 \mathrm{~h}$ while the animals were in an automated feeding system. Results are expressed as mean \pm SEM from 15 animals in each group. Statistics by unpaired $t$ tests which compare the values between drug-treated and control animals for each parameter. ${ }^{*} P<0.05$. 


\section{4h - fasted rats}

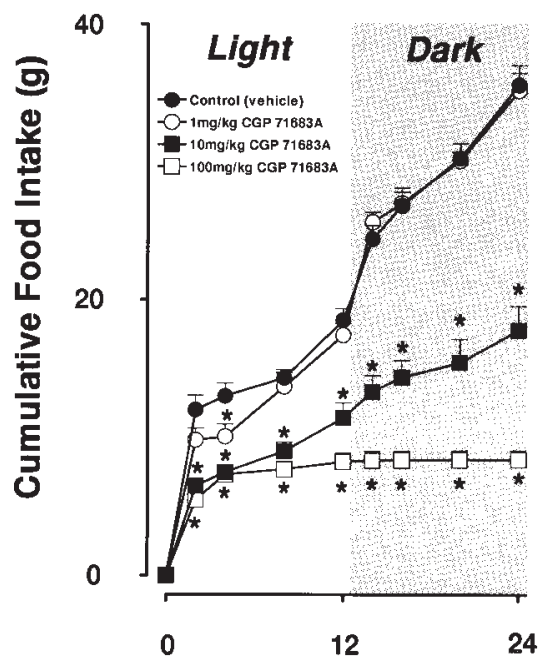

Time (h)
Free feeding rats

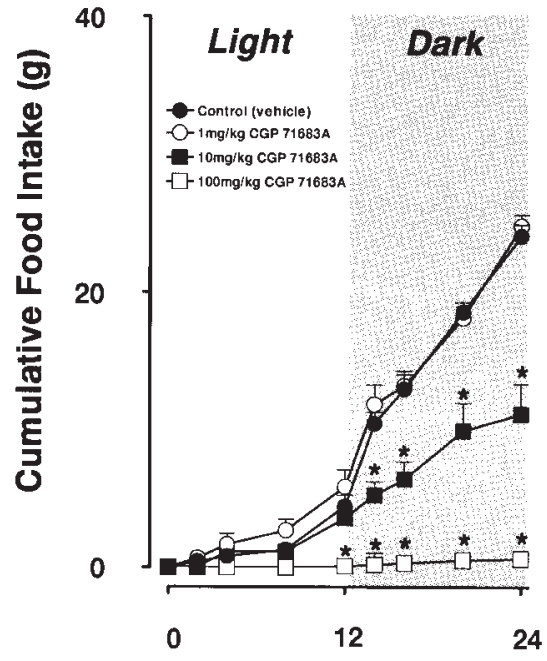

Time (h)
Figure 4. Effect of CGP 71683A on food intake in fasted and free-feeding rats. Rats fasted for $24 \mathrm{~h}$ or free-feeding animals were injected intraperitoneally either with vehicle (10\% DMSO, $2 \mathrm{ml} / \mathrm{kg}$ ) or CGP $71683 \mathrm{~A}(1,10$, and $100 \mathrm{mg} / \mathrm{kg})$ immediately after the beginning of the light phase (time 0). After injection of CGP 71683A, cumulative food intake was measured at different time periods over the following 24-h period. Results are expressed as mean \pm SEM from five animals in each group of the free-feeding and seven to nine animals in the 24 -h fasted studies, ${ }^{*} P<$ 0.05 vs. control.
However, because of the marked variation in this parameter, the difference was not quite statistically significant $(P<0.079)$.

Effect of insulin on food intake after administration of 100 $\mathrm{mg} / \mathrm{kg}$ CGP 71683 A to free-feeding rats (Fig. 5)

The purpose of these experiments was to investigate the ability of hypoglycemia to reverse the complete inhibition of food intake observed after administration of $100 \mathrm{mg} / \mathrm{kg}$ CGP 71683A in free-feeding rats. In comparison to the increase in food intake observed during the light phase in vehicle-treated freefeeding animals, food intake remained completely suppressed in animals pretreated $24 \mathrm{~h}$ earlier with $100 \mathrm{mg} / \mathrm{kg}$ CGP 71683A. Subcutaneous injection of insulin at the beginning of the light phase produced a similar and rapidly developing increase in food intake above the values recorded in either vehicle control or CGP 71683A-treated animals.

\section{Effect of CGP 71683A on conditioned taste aversion (Fig. 6)}

Prior treatment with lithium chloride on test day 1 induced a dose-dependent reduction in the ingestion of saccharine solution on test day 2 (only the effect of the highest dose of lithium chloride is shown). When CGP 71683A was injected on test day 1 , no subsequent aversion was observed at doses of 1 and $10 \mathrm{mg} / \mathrm{kg}$, whereas a significant inhibition of the ingestion of saccharine solution was observed at a dose of $100 \mathrm{mg} / \mathrm{kg}$. Comparison with the changes in food intake induced by CGP $71683 \mathrm{~A}$ in free-feeding rats (Fig. 4) indicates a clear separation between the aversive effects of the $Y_{5}$ antagonist and its effects on food intake at doses of 1 and $10 \mathrm{mg} / \mathrm{kg}$.

Effect of CGP 71683A on water intake in 24-h dehydrated/fasted rats (Fig. 7)

When injected into rats that had been both fasted and dehydrated for $24 \mathrm{~h}$, CGP 71683A did not significantly affect subsequent water intake during the light phase. On the other hand, during the dark phase, CGP 71683A produced a progressively developing and dose-dependent inhibition of water intake, particularly towards the end of the treatment period.

Effect of CGP 71683 A on food intake in streptozotocin diabetic rats (Fig. 8 )

Diabetes had been successfully induced as illustrated by the low plasma insulin levels $(0.76 \pm 0.13 \mathrm{ng} / \mathrm{ml}, n=9)$ and the high

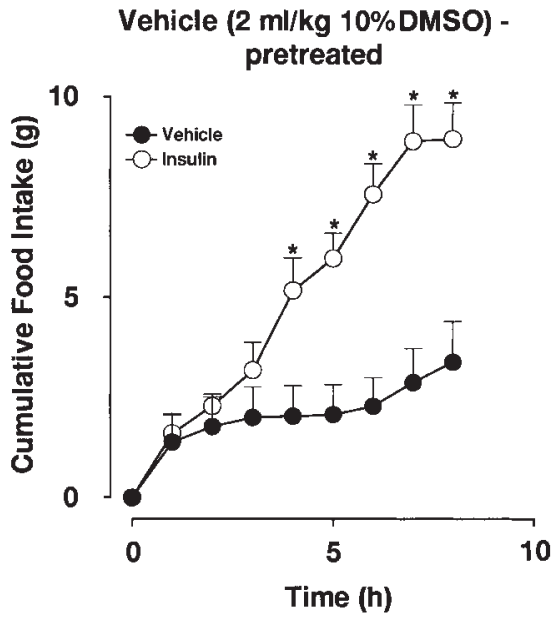

CGP 71683A (100 mg/kg) pretreated

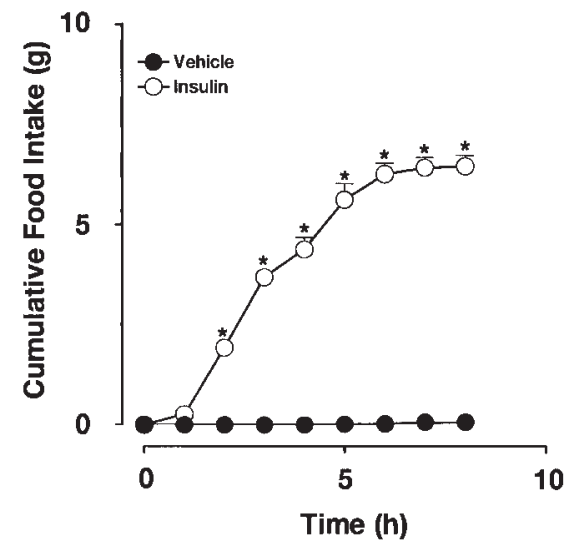

Figure 5. Effect of insulin on food intake in rats pretreated with CGP 71683A. Rats were injected intraperitoneally either with CGP 71683A $(100 \mathrm{mg} / \mathrm{kg})$ or vehicle $(10 \%$ DMSO, $2 \mathrm{ml} / \mathrm{kg}$ ). $24 \mathrm{~h}$ later, at the beginning of the light phase, rats from either group were injected subcutaneously either with vehicle $(0.9 \% \mathrm{NaCl}, 6 \mathrm{ml} / \mathrm{kg})$ or $60 \mathrm{IU}$ insulin (time 0 ) and cumulative food intake was measured over the following 8-h period. Results are expressed as the mean \pm SEM from five to six animals in each group, $* P<0.05$ vs. vehicle. 
plasma glucose levels $(620.8 \pm 68.3 \mathrm{ng} / \mathrm{dl}, n=9)$ in the control group of animals. Injection of CGP $71683 \mathrm{~A}$ reduced food intake in both the dark and light periods in a dose-dependent manner. However, in comparison with their normal counterparts, food intake during the experiment was higher in the diabetic than in normal free-feeding rats at each dose given. This was particularly evident in animals given the highest dose of $100 \mathrm{mg} / \mathrm{kg}$ where food intake was not completely suppressed as it was in the free-feeding animals.

\section{Chronic administration of CGP 71683A on food intake and} body weight (Fig. 9)

Food intake in the control group of animals was stable and averaged $\sim 27 \mathrm{~g} / \mathrm{d}$ during the 28 -d experimental period. Daily intraperitoneal injection of CGP 71683A (1,3, and $10 \mathrm{mg} / \mathrm{kg}$ per day i.p.) produced a significant and dose-dependent inhibition of food intake. The greatest fall in food intake occurred during the 3-d period after starting drug treatment. During this time period, the highest dose administered $(10 \mathrm{mg} / \mathrm{kg})$ resulted in almost complete cessation of food intake. Thereafter, despite continuous drug treatment, food intake progressively returned to control levels over the following $7 \mathrm{~d}$. Body weight in these growing animals increased progressively throughout the experimental period. Although CGP 71683A produced a reduction in body weight at all doses administered, only the fall observed after treatment with $10 \mathrm{mg} / \mathrm{kg}$ was statistically significant from controls. Despite the fact that food intake returned to control levels with time, body weight remained significantly decreased from control values for the duration of the experimental period.

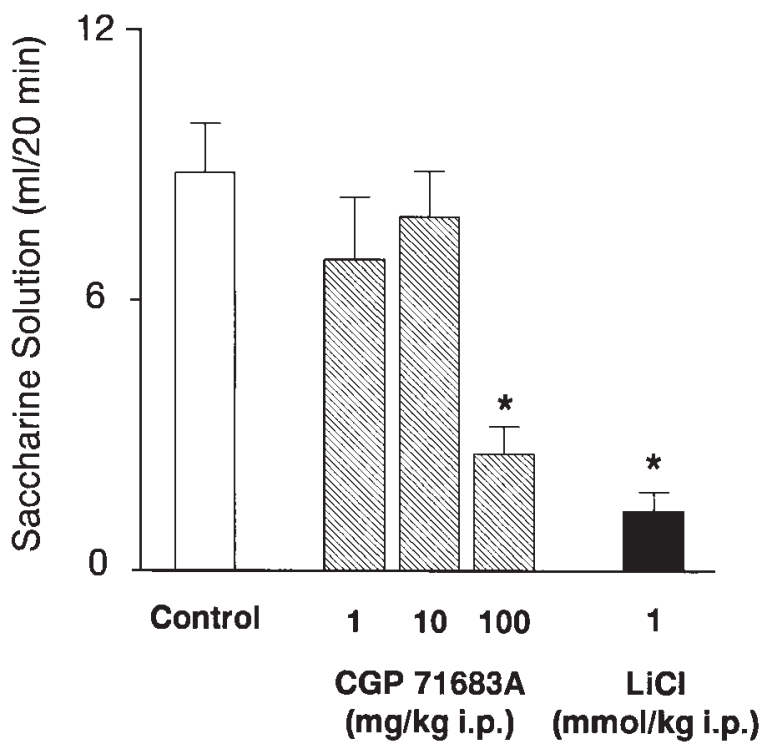

Figure 6. Effect of CGP 71683A on conditioned taste aversion. Over a 5-d period, rats were trained to drink a solution of sodium saccharine $(0.2 \%)$ for $20 \mathrm{~min}$ after a 14 -h period of water deprivation. $2 \mathrm{~d}$ later, rats were offered saccharine solution after another $14 \mathrm{~h}$ of water deprivation. Thereafter, the rats were injected intraperitoneally with $\mathrm{LiCl}(10,100$, and $1,000 \mu \mathrm{mol} / \mathrm{kg})$ or CGP $71683 \mathrm{~A}(1,10$, and 100 $\mathrm{mg} / \mathrm{kg})$. Control animals received the $10 \%$ DMSO vehicle $(2 \mathrm{ml} / \mathrm{kg})$. $2 \mathrm{~d}$ later the rats were again offered the sodium saccharine solution and the quantity consumed was determined (shown in figure). Results are expressed as the mean \pm SEM from six animals per group, $* P<0.05$ vs. control.

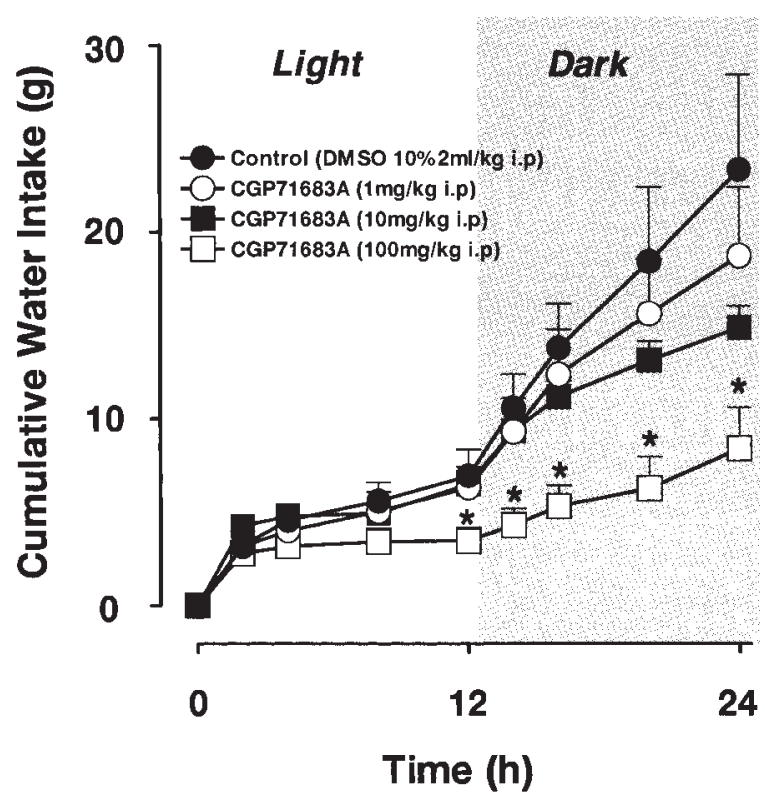

Figure 7. Effect of CGP 71683A on water intake in dehydrated rats. Rats deprived of water for $24 \mathrm{~h}$ were injected intraperitoneally either with vehicle $(10 \%$ DMSO, $2 \mathrm{ml} / \mathrm{kg}$ ) or CGP 71683A $(1,10$, and 100 $\mathrm{mg} / \mathrm{kg}$ ) immediately after the beginning of the light phase (time 0 ). After injection of CGP 71683A, cumulative water intake was measured at different time periods over the following 24-h period. Results are expressed as mean \pm SEM from six animals in each group, ${ }^{*} P<$ 0.05 vs. control.

Effect of chronic administration of CGP 71683A on food intake, body weight, and fat pad weight (Fig. 10 and Table III)

In these experiments, rats were injected intraperitoneally with CGP 71683A (10 mg/kg per day). Daily administration of CGP

Table III. Chronic Administration of CGP 71683A on Regional Fat Depots and Plasma Triglycerides, Glucose, and Insulin

\begin{tabular}{ll}
\hline \multicolumn{1}{c}{ Measured parameter } & \\
\hline Plasma triglycerides $(\mathrm{mg} / \mathrm{ml})$ & \\
$\quad$ Control & $1.22 \pm 0.10$ \\
CGP 71683A & $0.90 \pm 0.06^{*}$ \\
Pair fed & $0.88 \pm 0.06^{*}$ \\
Plasma glucose $(\mathrm{mg} / 100 \mathrm{ml})$ & \\
Control & $148.4 \pm 4.6$ \\
CGP 71683A & $146.1 \pm 6.0$ \\
Pair fed & $141.5 \pm 2.8$ \\
Plasma insulin $(\mathrm{ng} / \mathrm{ml})$ & \\
Control & $4.92 \pm 0.60$ \\
CGP 71683A & $3.35 \pm 0.45$ \\
Pair fed & $3.92 \pm 0.41$ \\
\end{tabular}

CGP 71683A was injected at the beginning of the light phase on 28 consecutive days $(10 \mathrm{mg} / \mathrm{kg}$ per day). At the end of the treatment period, the rats were killed, the fat pads were removed and weighed, and blood was taken. Results are expressed as mean \pm SEM from eight animals for each parameter. Statistics by one-way ANOVA. Post hoc test by the LSD procedure which compared differences between drug and pair fed groups and the control group. *Significantly different from control group at $P<0.05$. 


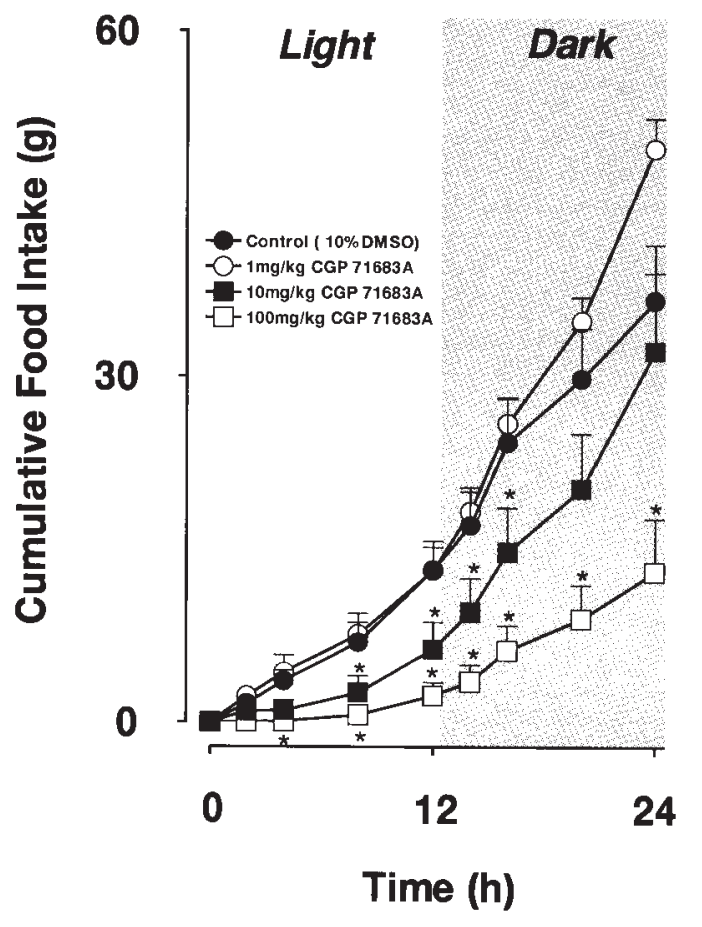

Figure 8. Effect of CGP 71683A on food intake in streptozotocin diabetic rats. Diabetic rats were injected intraperitoneally either with vehicle (10\% DMSO, $2 \mathrm{ml} / \mathrm{kg}$ ) or CGP 71683A (1, 10, and $100 \mathrm{mg} / \mathrm{kg})$ immediately after the beginning of the light phase (time 0 ). After injection of CGP 71683A, cumulative food intake was measured at different time periods over the following 24-h period. Results are expressed as mean \pm SEM from $8-10$ animals in each group, ${ }^{*} P<0.05$ vs. control.

71683A produced a significant reduction in food intake during the dark phase. A third group of animals were pair fed to those receiving CGP 71683A. Pair feeding produced a close match for food intake observed in the drug-treated animals. Chronic CGP 71683A treatment also produced the expected and maintained fall in body weight which was paralleled by the pair fed animals. Pair feeding produced a significant fall in the weight of the perirenal and epididymal fat pads. However, despite producing identical falls in food intake and body weight to the pair fed animals, the drug-treated animals had significantly lower fat pad weights (Fig. 10). In these experiments, CGP 71683A also produced a statistically significant fall in plasma triglycerides which was identical to that observed in pair fed animals. Neither pair feeding nor the administration of CGP 71683A produced significant changes in either plasma glucose or plasma insulin concentrations.

\section{Discussion}

The purpose of these experiments was to investigate the hypothesis of whether NPY $Y_{5}$ receptor blockade could induce acute and chronic reductions in food intake and body weight. This hypothesis was examined by studying NPY-induced feeding behavior in response to blockade of NPY Y F $_{5}$ receptors with a new highly selective nonpeptidic antagonist, CGP 71683A.

Within the hypothalamus, NPY is synthesized mainly in neurons of the arcuate nucleus (ARC). Axons from these cells pass through the lateral hypothalamus and release NPY onto cell bodies in the paraventricular nucleus (PVN) and the dorsomedial hypothalamus (DMH). The release of NPY in these two regions leads to the initiation of food intake. In lean rats, many studies have shown acute injections of NPY directly into the PVN and DMH or indirectly into the cerebral ventricles to substantially increase food intake in satiated rats $(2,3)$. Similar results are shown in the present studies.

Neurons in the ARC that synthesize and ultimately release NPY in the PVN play a key role in responding to reductions in body energy stores by initiating food intake. For example, in both fasted and streptozotocin diabetic rats, two models of energy deficit, the ARC, the PVN, and the DMH all show elevated NPY levels $(4,6)$. Both animal models also exhibit increased NPY mRNA gene expression in the ARC while NPY release from the PVN is concurrently increased (4, 7, 9-11). In free-feeding rats, NPY mRNA within the ARC is increased on transition from the light to the dark phase, whereas NPY levels are elevated in the PVN at this time. The above observations have been interpreted to suggest that the enhanced food intake of the dark phase as well as the hyperphagia of energydeprived rats are due to increased central NPY levels.

A temporal relationship between increased hypothalamic NPY levels and food intake has been established (12). Furthermore, inhibition of NPY synthesis or blockade of the action of
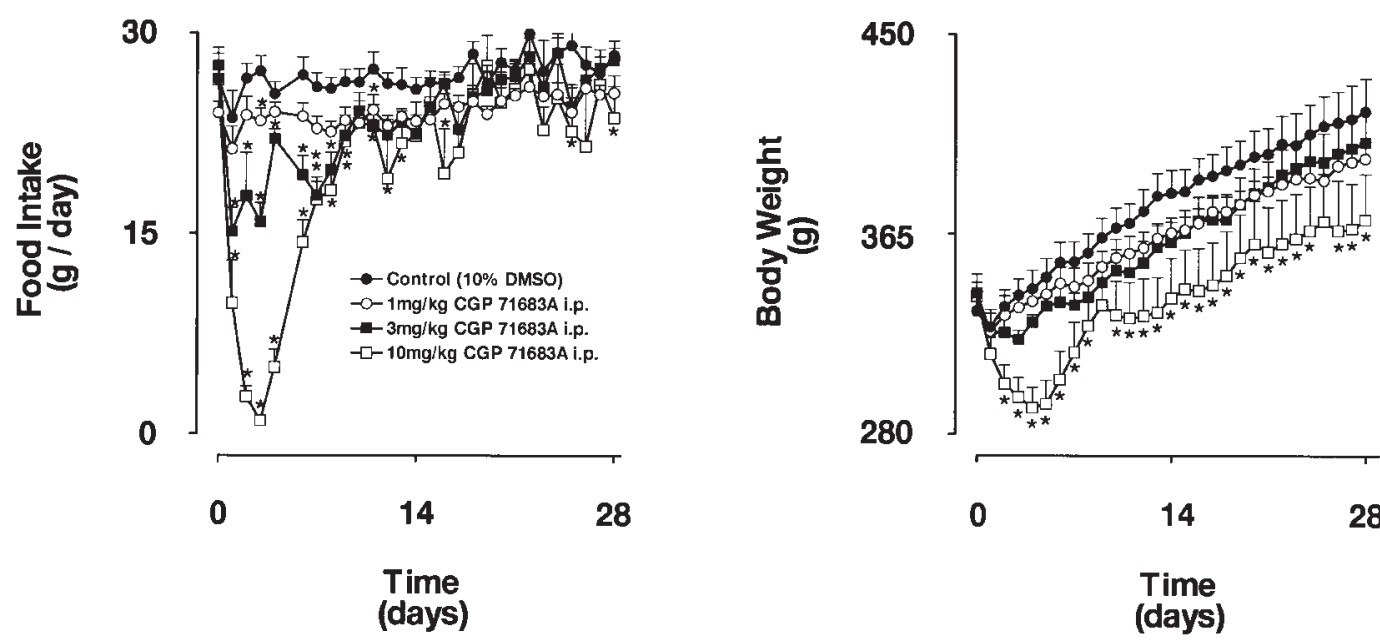

Figure 9. Effect of chronic administration of CGP 71683A on food intake and body weight. Rats were injected intraperitoneally with differing doses of CGP 71683A or an equal volume of the $10 \%$ DMSO vehicle (2 $\mathrm{ml} / \mathrm{kg}$ ). Injections were given daily at the beginning of the light phase for a total of $28 \mathrm{~d}$. Results are expressed as mean \pm SEM from six animals in each group, ${ }^{*} P<0.05$ vs. control. 

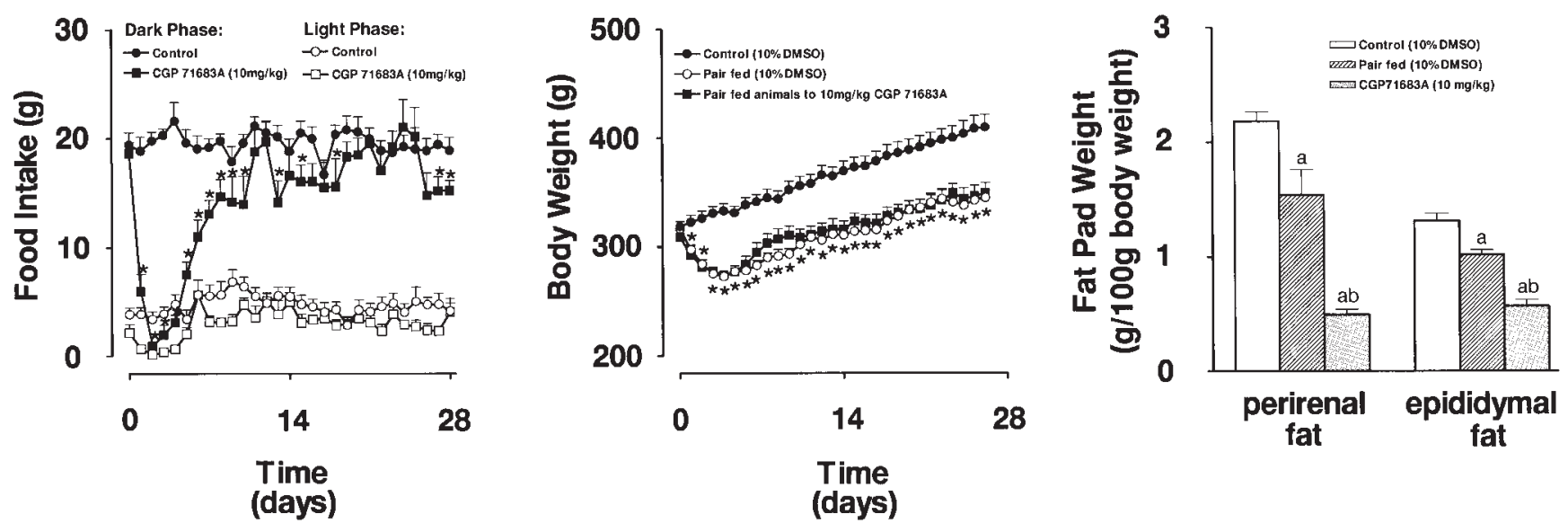

Figure 10. Effect of chronic administration of CGP 71683A on food intake, body weight, and fat pad weight. After a 3-d control period, rats were injected intraperitoneally with CGP $71683 \mathrm{~A}(10 \mathrm{mg} / \mathrm{kg})$ or the $10 \%$ DMSO vehicle $(2 \mathrm{ml} / \mathrm{kg})$. Injections were given daily at the beginning of the light phase for a total of $28 \mathrm{~d}$. A separate group of rats was pair fed every $12 \mathrm{~h}$ to the changes in food intake occurring in the CGP $71683 \mathrm{~A}-$ treated animals $24 \mathrm{~h}$ before. The symbols representing the pair fed animals are obscured since they lie almost exactly over those representing food intake in the drug-treated animals. At the end of the treatment period, the rats were killed and the fat pads were removed and weighed. Results are expressed as mean \pm SEM. There are eight rats in each group. ${ }^{*} P<0.05$ vs. control. ${ }^{\text {a }} P<0.05$ vs. control. ab $P<0.05$, significantly different from control and pair fed group.

NPY with antibodies or peptide receptor antagonists has been shown to suppress food intake in free-feeding and fooddeprived rats (14-16). These studies, along with the changes in NPY levels in hypothalamic nuclei described above, all suggest that NPY plays a physiologically important role in the control of food intake in both normal and energy-deprived rats.

In binding studies using cell lines stably expressing rat NPY receptors, CGP 71683A was shown to have a high affinity for the rat NPY $\mathrm{Y}_{5}$ receptor subtype $\left(\mathrm{IC}_{50}: 1.4 \mathrm{nM}\right)$. In contrast, CGP 71683A bound to rat $Y_{1}, Y_{2}$, and $Y_{4}$ receptors with at least 1,000-fold lower affinity. Among other rat receptors tested, the lowest selectivity was found against the rat $\alpha$-adrenergic $2 c$ receptor subtype (63-fold). Measurement of intracellular $\mathrm{Ca}^{2+}$ transients in LMTK cells stably expressing the human NPY $Y_{5}$ receptor indicated that CGP 71683A was devoid of agonistic activity and blocked NPY-induced $\mathrm{Ca}^{2+}$ transients through an insurmountable antagonism. Therefore, CGP 71683A can be considered as a potent and selective antagonist of the rat NPY $\mathrm{Y}_{5}$ receptor.

The increase in food intake induced by intracerebroventricular injection of exogenous NPY could be significantly inhibited by prior administration of CGP 71683A, suggesting that this compound enters the brain and is an effective antagonist of NPY-induced feeding acting through the NPY $\mathrm{Y}_{5}$ receptor.

In these studies, the NPY receptor antagonist CGP 71683A decreased food intake in streptozotocin diabetic, food-deprived, and free-feeding rats. In free-feeding rats, CGP 71683A dosedependently decreased food intake during the dark phase, a time when NPY levels in the hypothalamus are markedly increased. At a dose of $10 \mathrm{mg} / \mathrm{kg}$, CGP 71683A reduced food intake by $\sim 50 \%$. The maintenance of a normal pattern of feeding behavior and the absence of demonstrable aversion would indicate that the observed reduction in food intake was not due to a nonspecific effect of the compound. Indeed, experience with this compound has shown it to be well tolerated at low dosages. At the highest dose studied $(100 \mathrm{mg} / \mathrm{kg})$, food intake was completely suppressed in free-feeding and fasted rats. The failure to eat after administration of the compound at 100 $\mathrm{mg} / \mathrm{kg}$ was probably because of the marked aversion that was induced and which was reflected in observations of ruffled fur and a tendency towards reduced motility at this dosage. However, the animals were able to respond to the injection of a hypoglycemic dose of insulin with a robust increase in food intake. Therefore, at least one food stimulatory pathway remained intact and the animals were able to eat (but chose not to), after administration of CGP 71683A. Interestingly, dried brown nasal secretions were observed in animals $24 \mathrm{~h}$ after treatment with $100 \mathrm{mg} / \mathrm{kg}$ CGP 71683A and in a lighter and less uniform way in animals treated with $10 \mathrm{mg} / \mathrm{kg}$ CGP 71683A. The significance of these findings is not known but appeared not to be visually related either to the health of the animals or to their reduced food intake at low doses. However, a possible explanation may involve the known role of NPY in the control of nasal secretion (32). Interestingly, food intake in streptozotocin diabetic rats was not completely suppressed by the highest dose of CGP 71683A, suggesting that factors other than NPY contribute to the hyperphagia of this animal model. Clearly, the relative role of NPY and other neurotransmitters in the control of food intake in diabetic rats remains to be determined.

Not only did the administration of $10 \mathrm{mg} / \mathrm{kg}$ CGP 71683A acutely lower food intake in free-feeding rats it also did so when administered chronically. However, after 3-4 d of increasing efficacy, food intake returned progressively back towards normal and remained there for the duration of the 28 -d treatment period. This result would indicate that with continued NPY blockade counterregulatory mechanisms are induced to prevent starvation. This is not a surprising finding given the many overlapping systems that operate to control food intake (33). The return of food intake to control levels with chronic treatment is also seen with other appetite suppressants such as dexfenfluramine (34). Interestingly, in the present studies body weight fell with chronic NPY $\mathrm{Y}_{5}$ receptor blockade and remained suppressed even though food intake had returned to normal. This fall in body weight clearly occurred in two phases. The first paralleled the fall in food intake whereas the second did not and was associated at the end of the experiment with a 
decrease in fat pad weight below that observed in pair fed animals. It is possible that the additional decrease in fat pad weight may have been due to nonspecific effects related to the proximity of the very high local concentrations of CGP 71683A present at the injection site. However, in the brain, NPY has two effects on energy metabolism in addition to increase feeding. These are decreased brown fat thermogenesis and increased white fat lipoprotein lipase activity, both of which are secondary to increased central sympathetic outflow. The later fall in body weight and decrease in fat pad weight after chronic administration of CGP 71683A may then have been due to an increase in central sympathetic outflow rather than a decrease in food intake (35).

After release within the appetite-regulating centers of the brain, NPY acts on specific postsynaptic receptors to initiate food intake. NPY receptors, including the NPY $Y_{5}$ subtype, are present in the hypothalamus. However, despite extensive investigation, the subtype mediating the effects of NPY on food intake has remained controversial. Preliminary evidence suggesting a role for NPY $\mathrm{Y}_{5}$ receptors in the control of feeding came from the observation that the ability of a wide range of NPY peptide analogues to stimulate food intake correlated best with their affinity for the NPY $Y_{5}$ subtype $(18,19)$. These observations were supplemented recently by experiments demonstrating that intracerebroventricular injection of antisense oligonucleotides directed against the NPY $Y_{5}$ receptor inhibited both NPY and fasting induced food intake $(20,21)$. That the NPY $Y_{5}$ receptor is intimately involved in the response of food intake to NPY is given strong support by the results of the present study demonstrating that a highly selective NPY $Y_{5}$ antagonist inhibited NPY-induced food intake as well as appetite in free-feeding and energy-deprived rats.

Although accumulating evidence strongly supports a role for the NPY $Y_{5}$ receptor in NPY-induced food intake, there is conflicting evidence for the involvement of the NPY $Y_{1}$ receptor subtype. For example, although peptide and nonpeptide NPY $Y_{1}$ antagonists have been shown to inhibit both NPY and fasting-induced food intake, the known pharmacology of this receptor is not consistent with pharmacology of known NPY peptides which stimulate feeding. Furthermore, central administration of antisense oligonucleotides directed against the NPY $Y_{1}$ receptor or injection of a selective $Y_{1}$ antagonist appear to increase or decrease food intake depending on the study (23$26,36)$. These paradoxical observations could be interpreted to suggest that the NPY $Y_{1}$ receptor has dual activities in the control of NPY-induced food intake. Interestingly, inhibition of NPY $Y_{1}$ receptors has been shown to induce anxiety which may be a confounding factor contributing to the changes in food intake observed after blockade of NPY $Y_{1}$ receptors. Although evidence exists to support the involvement of NPY $Y_{5}$ and perhaps NPY $Y_{1}$ receptors in the control of food intake, other studies with selective peptide agonists suggest that other as yet unidentified receptor subtypes may also be involved (22, 23). Clearly, additional studies are needed to further define the relative contribution of receptor subtypes in addition to NPY $\mathrm{Y}_{5}$ in the control of NPY-induced food intake.

The role of NPY in the control of appetite is now well established, but its involvement in the control of drinking, an associated behavior, is less well characterized. Central administration of NPY stimulates water intake in rodents and rabbits, an effect believed to be independent of its orexigenic effects $(37,38)$. Recent studies have demonstrated increased prepro-
NPY mRNA levels in the ARC after water deprivation (39). These observations suggest that central NPY independently stimulates water as well as food intake. In these studies, CGP 71683A significantly inhibited dehydration-induced drinking in the absence of changes in food intake, suggesting that endogenous NPY acting through NPY $\mathrm{Y}_{5}$ receptors is independently involved in the control of both food and water intake.

In summary, the highly selective NPY $\mathrm{Y}_{5}$ antagonist CGP 71683A antagonized NPY-induced feeding and inhibited spontaneous food intake in diabetic, 24-h fasted, and free-feeding rats. With prolonged NPY $Y_{5}$ receptor blockade, the initial dramatic fall in food intake in free-feeding rats became progressively attenuated over time, suggesting that counterregulatory systems are induced to return food intake to normal. Although food intake returned to normal with prolonged NPY $\mathrm{Y}_{5}$ receptor blockade, body weight remained low. These data strongly support the hypothesis that the NPY $Y_{5}$ receptor subtype is involved in NPY-induced food intake and further suggest that NPY $\mathrm{Y}_{5}$ antagonists have a role to play in the treatment of obesity.

\section{Acknowledgments}

We would like to thank S. di Bello, D. Eichlisberger, D. Folio, L. Hartmann, F. Kilcher, F. Lugrin, D. Mannhart, G. Monnat, O. Peter, K. Pfeiffer, R. Schwaller, Z. Shaposhnik, H. Thomann, R. Wicki, and S. Zhou for technical assistance.

\section{References}

1. Heilig, M., and E. Widerlov. 1995. Neurobiology and clinical aspects of neuropeptide Y. Crit. Rev. Neurobiol. 9:115-136.

2. Stanley, B.G., and S.F. Leibowitz. 1984. Neuropeptide Y: stimulation of feeding and drinking by injection into the paraventricular nucleus. Life Sci. 35: 2635-2642.

3. Levine, A.S., and J.E. Morley. 1984. Neuropeptide Y: a potent inducer of consummatory behavior in rats. Peptides. 5:1025-1029.

4. Sahu, A., C.A. Sninsky, P.S. Kalra, and S.P. Kalra. 1990. Neuropeptide-Y concentration in microdissected hypothalamic regions and in vitro release from the medial basal hypothalamus-preoptic area of streptozotocin-diabetic rats with and without insulin substitution therapy. Endocrinology. 126:192-198.

5. Sahu, A., P.S. Kalra, and S.P. Kalra. 1988. Food deprivation and ingestion induce reciprocal changes in neuropeptide $\mathrm{Y}$ concentrations in the paraventricular nucleus. Peptides. 9:83-86.

6. Williams, G., J.S. Gill, Y.C. Lee, H.M. Cardoso, B.E. Okpere, and S.R. Bloom. 1989. Increased neuropeptide Y concentrations in specific hypothalamic regions of streptozocin-induced diabetic rats. Diabetes. 38:321-327.

7. Schwartz, M.W., A.J. Sipols, C.E. Grubin, and D.G. Baskin. 1993. Differential effect of fasting on hypothalamic expression of genes encoding neuropeptide Y, galanin, and glutamic acid decarboxylase. Brain Res. Bull. 31:361-367.

8. Beck, B., A. Stricker Krongrad, A. Burlet, J.P. Nicolas, and C. Burlet. 1990. Influence of diet composition on food intake and hypothalamic neuropeptide Y (NPY) in the rat. Neuropeptides. 17:197-203.

9. Hanson, E.S., N. Levin, and M.F. Dallman. 1997. Elevated corticosterone is not required for the rapid induction of neuropeptide $\mathrm{Y}$ gene expression by an overnight fast. Endocrinology. 138:1041-1047.

10. Marks, J.L., K. Waite, and M. Li. 1993. Effects of streptozotocininduced diabetes mellitus and insulin treatment on neuropeptide Y mRNA in the rat hypothalamus. Diabetologia. 36:497-502.

11. Brady, L.S., M.A. Smith, P.W. Gold, and M. Herkenham. 1990. Altered expression of hypothalamic neuropeptide mRNAs in food-restricted and fooddeprived rats. Neuroendocrinology. 52:441-447.

12. Sahu, A., C.A. Sninsky, and S.P. Kalra. 1997. Evidence that hypothalamic neuropeptide Y gene expression and NPY levels in the paraventricular nucleus increase before the onset of hyperphagia in experimental diabetes. Brain Res. 755:339-342.

13. Jhanwar Uniyal, M., B. Beck, C. Burlet, and S.F. Leibowitz. 1990. Diurnal rhythm of neuropeptide Y-like immunoreactivity in the suprachiasmatic, arcuate and paraventricular nuclei and other hypothalamic sites. Brain Res. 536: 331-334.

14. Hulsey, M.G., C.M. Pless, B.D. White, and R.J. Martin. 1995. ICV administration of anti-NPY antisense oligonucleotide: effects on feeding behav- 
ior, body weight, peptide content and peptide release. Regul. Pept. 59:207-214.

15. Shibasaki, T., T. Oda, T. Imaki, N. Ling, and H. Demura. 1993. Injection of anti-neuropeptide Y gamma-globulin into the hypothalamic paraventricular nucleus decreases food intake in rats. Brain Res. 601:313-316.

16. Dube, M.G., B. Xu, W.R. Crowley, P.S. Kalra, and S.P. Kalra. 1994. Evidence that neuropeptide $\mathrm{Y}$ is a physiological signal for normal food intake. Brain Res. 646:341-344.

17. Blomqvist, A.G., and H. Herzog. 1997. Y-receptor subtypes: how many more? Trends. Neurosci. 20:294-298.

18. Gerald, C., M.W. Walker, L. Criscione, E.L. Gustafson, C. Batzl Hartmann, K.E. Smith, P. Vaysse, M.M. Durkin, T.M. Laz, D.L. Linemeyer, et al. 1996. A receptor subtype involved in neuropeptide-Y-induced food intake. $\mathrm{Na}$ ture. 382:168-171.

19. Wyss, P., A. Stricker Krongrad, L. Brunner, J. Miller, A. Crossthwaite, S. Whitebread, and L. Criscione. 1998. The pharmacology of neuropeptide Y (NPY) receptor-mediated feeding in rats characterizes better Y5 than Y1, but not Y2 or Y4 subtypes. Regul. Pept. 75:363-371.

20. Schaffhauser, A.O., A. Stricker Krongrad, L. Brunner, F. Cumin, C. Gerald, S. Whitebread, L. Criscione, and K.G. Hofbauer. 1997. Inhibition of food intake by neuropeptide Y Y5 receptor antisense oligodeoxynucleotides. Diabetes. 46:1792-1798.

21. Tang Christensen, M., P. Kristensen, and P.J. Larsen. 1997. Central administration of NPY Y5 receptor antisense oligonucleotides reduces food intake and blocks NPY induced feeding in male rats. Society Neurosci. 23:1345. (Abstr.)

22. Broqua, P., J.G. Wettstein, M.N. Rocher, B. Gauthier Martin, P.J. Riviere, J.L. Junien, and S.G. Dahl. 1996. Antinociceptive effects of neuropeptide $\mathrm{Y}$ and related peptides in mice. Brain Res. 724:25-32

23. O'Shea, D., D.G. Morgan, K. Meeran, C.M. Edwards, M.D. Turton, S.J. Choi, M.M. Heath, I. Gunn, G.M. Taylor, J.K. Howard, et al. 1997. Neuropeptide $\mathrm{Y}$ induced feeding in the rat is mediated by a novel receptor. Endocrinology. 138:196-202.

24. Lopez Valpuesta, F.J., J.W. Nyce, T.A. Griffin Biggs, J.C. Ice, and R.D. Myers. 1996. Antisense to NPY-Y1 demonstrates that Y1 receptors in the hypothalamus underlie NPY hypothermia and feeding in rats. Proc. R. Soc. Lond. B. Biol. Sci. 263:881-886.

25. Heilig, M. 1995. Antisense inhibition of neuropeptide Y (NPY)-Y1 receptor expression blocks the anxiolytic-like action of NPY in amygdala and paradoxically increases feeding. Regul. Pept. 59:201-205.
26. Kanatani, A., A. Ishihara, S. Asahi, T. Tanaka, S. Ozaki, and M. Ihara. 1996. Potent neuropeptide Y Y1 receptor antagonist, 1229U91: blockade of neuropeptide Y-induced and physiological food intake. Endocrinology. 137: 3177-3182.

27. Doods, H.N., H.A. Wieland, W. Engel, W. Eberlein, K.D. Willim, M. Entzeroth, W. Wienen, and K. Rudolf. 1996. BIBP 3226, the first selective neuropeptide Y1 receptor antagonist: a review of its pharmacological properties. Regul. Pept. 65:71-77.

28. Bradford, M.M. 1976. A rapid and sensitive method for the quantitation of microgram quantities of protein utilizing the principle of protein-dye binding. Anal. Biochem. 72:248-254.

29. Stricker Krongrad, A., B. Beck, and C. Burlet. 1996. Enhanced feeding response to neuropeptide $\mathrm{Y}$ in hypothalamic neuropeptide $\mathrm{Y}$-depleted rats. Eur. J. Pharmacol. 295:27-34.

30. Larue, C. 1978. Oral cues involved in the rat's selective intake of fats. Chem. Senses Flavour. 3:1-6.

31. Ramirez, I. 1992. Chemoreception for fat: do rats sense triglycerides directly? Appetite. 18:193-206.

32. Lacroix, J.S., and B.L. Mosimann. 1996. Attenuation of allergen-evoked nasal responses by local pretreatment with exogenous neuropeptide $\mathrm{Y}$ in atopic patients. J. Allergy Clin. Immunol. 98:611-616.

33. Levine, A.S., and C.J. Billington. 1997. Why do we eat? A neural systems approach. Annu. Rev. Nutr. 17:597-619.

34. Li, B.H., and N.E. Rowland. 1996. Effect of chronic dexfenfluramine on Fos in rat brain. Brain Res. 728:188-192.

35. Billington, C.J., J.E. Briggs, S. Harker, M. Grace, and A.S. Levine. 1994. Neuropeptide $\mathrm{Y}$ in hypothalamic paraventricular nucleus: a center coordinating energy metabolism. Am. J. Physiol. 266:R1765-R1770.

36. Schaffhauser, A.O., S. Whitebread, R. Haener, K.G. Hofbauer, and A. Stricker Krongrad. 1998. Neuropeptide Y Y1 receptor antisense oligodeoxynucleotides enhance food intake in energy-deprived rats. Regul. Pept. 75:417-423.

37. Morley, J.E., and J.F. Flood. 1989. The effect of neuropeptide Y on drinking in mice. Brain Res. 494:129-137.

38. Pau, M.Y., K.Y. Pau, and H.G. Spies. 1988. Characterization of central actions of neuropeptide $\mathrm{Y}$ on food and water intake in rabbits. Physiol. Behav. 44:797-802.

39. O'Shea, R.D., and A.L. Gundlach. 1995. NPY mRNA and peptide immunoreactivity in the arcuate nucleus are increased by osmotic stimuli: correlation with dehydration anorexia. Peptides. 16:1117-1125. 